\title{
Multipropriedade imobiliária: uma análise da solidariedade na cobrança do Imposto sobre a Propriedade Predial e Territorial Urbana
}

\author{
Time-sharing: an analysis of solidarity in the collection of the Urban Property Tax
}

\author{
Marcelo Sampaio Siqueira* \\ Natercia Sampaio Siqueira ${ }^{* *}$ \\ Valéria Moraes Lopes ${ }^{* * *}$
}

\section{REFERÊNCIA}

LOPES, Valéria Moraes; SIQUEIRA, Marcelo Sampaio; SIQUEIRA, Natercia Sampaio. Multipropriedade imobiliária: uma análise da solidariedade na cobrança do Imposto sobre a Propriedade Predial e Territorial Urbana. Revista da Faculdade de Direito da UFRGS, Porto Alegre, n. 47, p. 179-200, dez. 2021. DOI: https://doi.org/10.22456/0104-6594.107683.

\section{RESUMO}

O presente artigo trata da multipropriedade imobiliária e da hipótese de incidência do Imposto sobre a Propriedade Predial e Territorial Urbana (IPTU), pelo qual se empreende uma análise da sujeição passiva dos multiproprietários e da ocorrência do fato gerador da obrigação tributária principal, considerando o tratamento dado ao instituto pelo Direito Civil como forma de expressão contemporânea da propriedade. A pesquisa se justifica em face da necessidade de se apurar com exatidão o polo passivo da obrigação tributária na ocorrência de fracionamento da propriedade por período e na existência de várias matrículas para cada multiproprietário. $\mathrm{O}$ objetivo deste artigo é analisar o polo passivo da relação tributária, levando em consideração a posição dos tribunais e dos doutrinadores acerca do artigo 110 do CTN. Para o atingimento de tal finalidade, utilizou-se como metodologia as pesquisas bibliográfica, doutrinária e jurisprudencial e o método hipotético-dedutivo. Ao final, constatou-se que não constitui quebra de conteúdo de Direito Privado, no âmbito do assunto multipropriedade, a cobrança solidária pelo Município do tributo predial sobre a unidade.

\section{PALAVRAS-CHAVE}

Time-sharing. Civil. IPTU. Sujeito passivo. Solidariedade.

\begin{abstract}
The present article analyses the time-sharing and the hypothesis of incidence of the Urban Property and Territorial Property Tax, analyzing the passive subjection of the multi-owners and the occurrence of the chargeable event of the main tax obligation, considering the treatment given to the institute by civil law as a contemporary form of expression of property. The research is justified due to the need to determine precisely the passive pole of the tax obligation when occurs the franchising of property for a period and the existence of several registrations for each multi-owner. The purpose of this article is to analyze the passive pole of the tax relationship, considering the position of the courts and the indoctrinators about article 110 of the National Tributary Code. To achieve this purpose a doctrinal, bibliographic and jurisprudential research was performed
\end{abstract}

\footnotetext{
*Doutor em Direito Constitucional pela Universidade de Fortaleza (Unifor). Mestre em Direito pela Universidade Federal do Ceará (UFC). Professor Titular do Centro Universitário 7 de Setembro (UNI7). Professor do PPGD - Mestrado em direito da UNI7. Procurador do Município de Fortaleza. Email:msiqueira@siqueiraibiapina.com.br.

**Doutora em Direito Constitucional pela Universidade de Fortaleza (Unifor). Mestre em Direito Tributário pela Universidade Federal de Minas Gerais (UFMG). Professora do PPGD da Universidade de Fortaleza (Unifor). Procuradora do Município de Fortaleza.

***Mestranda em Direito pelo Centro Universitário 7 de Setembro (UNI7). Especialista em Direito Processual Civil pela Escola Superior da Magistratura do Estado do Ceará (Esmec) da Universidade Federal do Ceará (UFC). Procuradora do Município de Fortaleza.
} 
and the hypothetical-deductive methodology was adopted. In the end, it was found that it does not constitute a breach of private law content, in the context of the multiproperty issue, the solidarity collect by the Municipality of the tribute on the unity.

\section{KEYWORDS}

Time-sharing. Civil. IPTU. Passive subject. Solidarity.

\section{SUMÁRIO}

1 Introdução. 2 Breves contornos da multipropriedade no contexto brasileiro. 3 A multipropriedade imobiliária como hipótese de incidência do Imposto sobre a Propriedade Predial e Territorial Urbana (IPTU). 4 Os artigos 109 e 110 do Código Tributário. 5 Direitos que se sucedem. 6 Sujeito passivo do IPTU e multipropriedade. 7 Conclusão. Referências.

\section{INTRODUÇÃO}

Partindo-se do conceito contemporâneo de propriedade no Brasil, dentro da sua convergente funcionalização social e econômica, cujo arcabouço encontra sede na Constituição Federal e é informado pelos princípios da dignidade da pessoa humana e da justiça social, fazendo parte de um engenhoso sistema composto pelo Código Civil e outros microssistemas, tal como o Estatuto da Cidade, analisar-se-á a hipótese de incidência do Imposto sobre a Propriedade Predial e Territorial Urbana (IPTU) sobre a multipropriedade imobiliária, perquirindo-se acerca do sentido que lhe pode ser atribuído pelo Direito Tributário. Em síntese, buscar-se-á investigar o polo passivo da relação tributária, levando em consideração a posição dos tribunais e dos doutrinadores acerca do artigo 110 do CTN.

A competência impositiva do IPTU está encartada na Constituição Federal, em seu artigo 156, inciso I, atribuída aos Municípios. Uma das mais árduas tarefas do exercício dessa competência tem sido alcançar a multifacetária realidade econômica. Nesse contexto, emerge a denominada multipropriedade, igualmente conhecida por time-sharing ou aproveitamento da propriedade imobiliária por turno.

O referido instituto, apesar de bem explorado em outros países, originando-se possivelmente na Europa e posteriormente se espraiando pelos Estados Unidos, ainda carece de uma maior regulamentação legal no Brasil, mesmo considerando-se a recente publicação da Lei n ${ }^{\circ}$ 13.777, de 20 de dezembro de 2018. No entanto, como a ciência do direito não pode se quedar inerte em relação aos influxos sociais, pouco a pouco se vem lançando mão da configuração da multipropriedade relativamente a bens móveis e imóveis, despertando na doutrina e jurisprudência pátria discussão sobre a natureza dessa relação jurídica.

A multipropriedade, que consiste no uso, gozo e fruição de um bem por vários detentores de forma exclusiva em determinado espaço de tempo previamente convencionado 
no título aquisitivo, comporta várias espécies, tais como a hoteleira, a acionária, etc. No entanto, o eixo deste trabalho consiste na multipropriedade imobiliária por força da conexão a ser estabelecida com o Imposto Sobre a Propriedade Predial e Territorial Urbana. O desenvolvimento do tema toma como ponto de partida a apresentação dos contornos do instituto da multipropriedade no Brasil, centrando-o na concepção de elemento catalisador das funções social e econômica da propriedade e estabelecendo uma conexão com o Direito Tributário, mais precisamente sob o ponto de vista da hipótese de incidência do Imposto sobre a Propriedade Territorial e Predial Urbana (IPTU).

$\mathrm{Na}$ sequência, investiga-se o sentido de propriedade adotado pelo legislador constituinte originário para fixar a competência impositiva do Município em relação ao IPTU, com o intuito de se delimitar a correspondente hipótese de incidência tributária. Para tanto, utiliza-se o método hipotético-dedutivo para realizar pesquisa qualitativa e bibliográfica.

A partir dessa moldura, passa-se ao esquadrinhamento da relação jurídico-tributária, principalmente a sujeição passiva, com o fito de se perquirir a responsabilidade tributária (sentido amplo) na multipropriedade imobiliária quanto ao Imposto sobre a Propriedade Territorial e Predial Urbana (IPTU).

\section{BREVES CONTORNOS DA MULTIPROPRIEDADE NO CONTEXTO BRASILEIRO}

A propriedade imobiliária, instituto que remonta à Antiguidade Clássica e constitui objeto de estudo do Direito Romano desde a fase arcaica, vem passando por inúmeras conformações até os dias de hoje. Do caráter absoluto ao relativo, extrai-se, segundo Marcelo Sampaio Siqueira (2018, p. 32), que

\footnotetext{
[a] evolução sobre o tema propriedade aufere contornos ainda mais complexos, quando essa deixa de ser considerada um mero poder individual de apropriação e fruição, de natureza meramente particular, e passa a ser analisada, considerando-se as relações pessoais, na sua dimensão social e econômica, já que alguns tipos de propriedade constituem um importante fator de produção, cuja importância é medular no desenvolvimento do sistema capitalista.
}

Em sua nova roupagem, considerando os princípios da Carta de 1988, solidariedade, dignidade da pessoa humana e função social, a propriedade imobiliária, já no século XX, passou a ser funcionalizada em prol da coletividade, obrigando o titular do bem a exercer o 
seu direito em atendimento aos ditames sociais e econômicos impostos pelo sistema jurídico vigente. Eis o que se pode inferir de função social da propriedade.

Em torno desse eixo, Juliana Werneck de Camargo (2008, p. 25) expõe:

[e] essa ordem de licitude do titular do direito de propriedade, especialmente a imobiliária urbana, foi ganhando contornos sociais, deixando de ser absoluta e ilimitada para existir e ser legítima segundo uma utilidade comunitária ou social que deve ser buscada pelo titular no exercício de seu direito. Ou seja, a ordem jurídica, por assimilação paulatina do princípio da função social da propriedade, vem reconhecendo que a coletividade tem o direito de verem atendidas certas utilidades de cunho social pelo titular do direito do bem em questão, introduzindo na esfera jurídica desse titular a obrigação de cumprir uma finalidade social e que dá validade ao seu direito de propriedade.

O Código Civil atual (Lei $\mathrm{n}^{\mathrm{o}}$ 10.406, de 10 de janeiro de 2002) não apresentou um conceito de propriedade, ocupando-se de elencar os poderes inerentes ao titular do direito, como se vê do pronunciamento de Juliana Cavalcante dos Santos (2014, p. 554) a respeito:

[r]eiterando o dito, as formas de exercício do direito de propriedade são a de usar, gozar, dispor e reaver - ou reivindicar - de quem injustamente a possua ou a detenha, correspondentes ao conteúdo econômico da propriedade. Portanto, o Código Civil disciplina o direito de propriedade em sua perspectiva estrutural, limitando o art. 1.228 a descrever os poderes do titular.

A par da funcionalização da propriedade, a sociedade pós-moderna vem se caracterizando pela diversidade de novos engenhos nas relações privadas, o que não poderia deixar de alcançar o direito de propriedade. Como nova forma de expressão contemporânea da propriedade, emerge o instituto da multipropriedade, com raízes estrangeiras, que passou a contar no final de 2018 com regulamentação expressa em lei no Brasil ${ }^{1}$.

A multipropriedade é um engenho pensado e criado primordialmente por incorporadores imobiliários desejosos de edificar grandes empreendimentos em locais turísticos, consistente na organização de grandes grupos para financiar a construção de edifícios com várias unidades autônomas, mas em número inferior ao dos membros do grupo adquirente. A engenhosidade da ideia não é baratear o preço da unidade, mas promover a aquisição das unidades em edificação por um maior número de pessoas, muitas vezes estranhas, reunidas em grupos, que compartilhariam as faculdades da unidade autônoma, não mais destinada individualmente a cada adquirente, mediante deliberação convencional. Em

\footnotetext{
1 “Art. 1.358-C. Multipropriedade é o regime de condomínio em que cada um dos proprietários de um mesmo imóvel é titular de uma fração de tempo, à qual corresponde a faculdade de uso e gozo, com exclusividade, da totalidade do imóvel, a ser exercida pelos proprietários de forma alternada.” (BRASIL, 2018)
} 
síntese, esse tipo de organização favorece a viabilização econômica do empreendimento, já que o compartilhamento das unidades construídas reduz sensivelmente os valores efetivamente desembolsados por cada adquirente, desejoso, por exemplo, de possuir uma casa de veraneio, em comparação aos praticados se a unidade tivesse um único comprador (SIQUEIRA; SIQUEIRA, 2017, p.66).

Em obra específica sobre a multipropriedade imobiliária, Gustavo Tepedino (1993, p. 1, grifos do autor) elaborou o seguinte conceito:

[c]om o termo multipropriedade designa-se, genericamente, a relação jurídica de aproveitamento econômico de uma coisa móvel ou imóvel, repartida em unidades fixas de tempo, de modo que diversos titulares possam, cada qual a seu turno, utilizar-se da coisa com exclusividade e de maneira perpétua.

[...]

A multipropriedade apresenta-se, assim, como direito que pode ser perpétuo quanto à duração, embora temporário quanto ao seu exercício, peculiaridade que lhe valeu, em doutrina, a referência a um véritable droit à eclipses.

Do conceito apresentado destacam-se os seguintes elementos: a) bem móvel ou imóvel; b) pluralidade de titulares de direito sobre a coisa; c) repartição do aproveitamento econômico (fragmentação de uso e gozo); c) turnos intercorrentes de aproveitamento definidos com exclusividade; d) utilização exclusiva, sem o concurso dos demais nos períodos previamente definidos (SIQUEIRA; SIQUEIRA, 2017, p. 67).

A natureza jurídica da multipropriedade ${ }^{2}$ antes da citada legislação (Lei $\mathrm{n}^{\circ}$ 13.777/2018) gerava controvérsias. Uma corrente a considerava como de Direito Pessoal, em face do liame existente entre os pactuantes do contrato de time-sharing e o bem objeto da avença, escudando-se na tipicidade e taxatividade dos Direitos Reais por força de a multipropriedade não constar no rol previsto no artigo 1.225 do Código Civil, em contraponto à outra tese, que a tinha como de natureza real com todos os consectários daí decorrentes. Jurisprudencialmente, o Superior Tribunal de Justiça (STJ), a quem compete uniformizar o direito infraconstitucional, no julgamento do Recurso Especial (REsp) $n^{\circ}$ 1.546.165/SP, datado de 26 de abril de 2016, por maioria dos membros da Terceira Turma, assentou que a multipropriedade imobiliária se reveste da natureza de Direito Real ${ }^{3}$.

\footnotetext{
${ }^{2}$ Sobre a natureza jurídica da multipropriedade e a modalidade hoteleira, Venosa $(2019$, p. 19) entende que não pode ser caracterizada uma relação obrigacional regulada pela Lei 8.245/81.

3 "PROCESSUAL CIVIL E CIVIL. RECURSO ESPECIAL. EMBARGOS DE TERCEIRO. MULTIPROPRIEDADE IMOBILIÁRIA (TIME-SHARING). NATUREZA JURÍDICA DE DIREITO REAL. UNIDADES FIXAS DE TEMPO. USO EXCLUSIVO E PERPÉTUO DURANTE CERTO PERÍODO ANUAL. PARTE IDEAL DO MULTIPROPRIETÁRIO. PENHORA. INSUBSISTÊNCIA. RECURSO ESPECIAL
} 
A discussão tratada deixa de ser relevante, já que a legislação brasileira, com os acréscimos postos no Código Civil e na Lei dos Registros Públicos (Lei nº 6.015, de 31 de dezembro de 1973) pela Lei $n^{\circ} 13.777 / 2018$, passou a abordar a multipropriedade imobiliária como uma espécie de condomínio, não restando dúvida do seu caráter real.

No entanto, a depender de como for organizada a multipropriedade ou time sharing, poderá ser classificada em três diferentes espécies: a) multipropriedade acionária; b) multipropriedade real; e c) multipropriedade obrigacional. A primeira ganha essa terminologia pelo fato de o equipamento ter sido edificado por uma sociedade anônima constituída para esse fim, cujos acionistas seriam os detentores dos direitos de posse temporária das unidades que compõem o edifício. A segunda se caracteriza não por contrato social ou estatuto, mas pela propriedade em comum do edifício, sobre a qual os particulares gozariam de Direito Real, haja vista tratar-se de espécie de propriedade em condomínio. A terceira espécie de multipropriedade se concretiza quando a posse compartilhada em turnos intercorrentes das unidades autônomas da edificação seja formalizada por uma espécie de contrato entre os interessados, sendo, portanto, o proprietário pessoa estranha aos detentores do direito de posse $^{4}$. Logo, a espécie de multipropriedade vai depender da forma de constituição do empreendimento organizado pelo empreendedor. Nesse diapasão, a multipropriedade poderia ser classificada como típica (tratada como espécie de condomínio - Direito Real) e atípica.

Na multipropriedade típica, conforme a recente lei, o empreendimento pertenceria a todos os multiproprietários, a quem caberia uma fração ideal, constituindo uma espécie de condomínio ou condomínio edilício, regulado pelo Código Civil de 2002, a depender de sua instituição, sendo, portanto, Direito Real. Já na atípica a propriedade seria de uma única pessoa jurídica, ou um pequeno grupo formando um condomínio, e existiria contrato regulando a posse/uso temporária dos chamados multiproprietários, terceiros estranhos aos condôminos. Seria espécie de Direito Pessoal: multipropriedade obrigacional ou acionária, a depender do modo como se deu sua constituição.

Questão interessante a destacar é que na multipropriedade imobiliária, no lapso temporal destinado a cada multiproprietário caberiam as faculdades da propriedade sobre unidade autônoma de forma plena, com as devidas limitações de ordem constitucional

CONHECIDO E PROVIDO. [...] (REsp 1546165/SP, Rel. Ministro RICARDO VILLAS BÔAS CUEVA, Rel. p/ Acórdão Ministro JOÃO OTÁVIO DE NORONHA, TERCEIRA TURMA, julgado em 26/04/2016, DJe 06/09/2016)" (BRASIL, 2016).

${ }^{4}$ Sobre a questão vide Melo (2011, p. 25): "Embora a doutrina acabe por não enunciar essa espécie de multipropriedade, parte da jurisprudência nacional mais conservadora classifica os contratos de aproveitamento por tempo como mero direito obrigacional, alguns definindo o instituto como arrendamento.”. 
(exemplo: função social da propriedade), legal (exemplo: direito de vizinhança) e regimental (exemplo: convenção e regimento do condomínio).

Em síntese, o instituto da multipropriedade é presente no Brasil e sua organização como Direito Real não pode ser mais descartada, considerando-se a legislação do final de 2018, que a equipara a uma espécie de condomínio edilício ${ }^{5}$, regulado no Livro III - Do Direito das Coisas, Título III - Da Propriedade, do Código Civil de 2002.

A discussão acerca da natureza e da relação jurídica criada pela multipropriedade (perpetuidade-duração e temporalidade-exercício) produz uma certa perplexidade não só no Direito Civil como em outros ramos do Direito, em especial no Direito Tributário quanto à hipótese de incidência do Imposto sobre a Propriedade Territorial e Predial Urbana (IPTU) e à legitimidade da cobrança, considerando a existência de vários proprietários para uma mesma unidade, cuja abordagem será desenvolvida em sequência.

\section{A MULTIPROPRIEDADE IMOBILIÁRIA COMO HIPÓTESE DE INCIDÊNCIA DO IMPOSTO SOBRE A PROPRIEDADE PREDIAL E TERRITORIAL URBANA (IPTU)}

A Constituição Federal, em seu artigo 156, inciso I, estabelece que "compete aos Municípios instituir imposto sobre propriedade predial e territorial urbana" e que "a propriedade urbana cumpre sua função social quando atende às exigências fundamentais de ordenação da cidade expressas no plano diretor (art. 182, $\S 2^{\circ}$ ). A instituição de tributo sobre a propriedade imobiliária, além do aspecto arrecadatório, considerando também a função social e o princípio da solidariedade, tem um fim extrafiscal de estimular a política habitacional em um país extremamente desigual ${ }^{6}$.

O Código Tributário Nacional (CTN - Lei $\mathrm{n}^{\circ} 5.172$, de 25 de outubro de 1966), recepcionado pela Constituição de 1998, no seu artigo 32 e seguintes define a competência dos Municípios para tributar a propriedade predial urbana e define como contribuintes no artigo 34 o proprietário do imóvel, o titular do seu domínio útil, ou o seu possuidor a qualquer

\footnotetext{
${ }^{5}$ Vide sobre o assunto o Enunciado 89 da I Jornada de Direito Civil: "O disposto nos arts. 1.331 a 1.358 do novo Código Civil aplica-se, no que couber, aos condomínios assemelhados, tais como loteamentos fechados, multipropriedade imobiliária e clubes de campo.” (CONSELHO DA JUSTIÇA FEDERAL, 2002).

${ }^{6}$ Segundo Cintia Estefania Fernandes (2011, p. 120), o arcabouço constitucional da tributação imobiliária há de ser compreendido sob novo paradigma: "A tributação imobiliária, a partir do advento da Constituição Federal de 1988 e do Estatuto da Cidade, passou a ser instrumento imprescindível não só para fins de arrecadação tributária, a qual deve estar fulcrada na isonomia e na solidariedade, mas também para ordenação responsável do território de um Brasil cuja Carta Magna impõe o Direito Coletivo ao Planejamento urbano adequado à função social da propriedade e da Cidade. Este é o novo paradigma a ser observado".
} 
título. Parece não remanescer dúvida de que a multipropriedade imobiliária, como uma espécie de unidade autônoma, representada por um apartamento ou sala, por exemplo, configura-se como fato gerador do IPTU, principalmente após a publicação da Lei $\mathrm{n}^{\circ}$ 13.777/2018, que equiparou a multipropriedade a uma espécie de condomínio. A questão que se apresenta mais complexa é a sujeição passiva, considerando-se a temporalidade do exercício do direito de propriedade pelos multiproprietários.

A nova regulamentação da multipropriedade no entanto não traz regra específica acerca da legitimidade passiva ou aventa se há solidariedade ${ }^{7}$ entre os multiproprietários no tocante à obrigação tributária. Essa lacuna torna desafiador para o intérprete e aplicador da lei tributária responder a quem e como os Municípios devem proceder para aferir o produto do tributo predial, tendo em vista a necessidade de se alcançar um conceito do instituto em consonância com os Direitos Civil e Tributário que possibilite uma escorreita aplicação da exação tributária.

Observa-se que o artigo 1.358-J do Código Civil, acrescentado pela Lei $\mathrm{n}^{\circ}$ 13.777/2018, que trata das obrigações do multiproprietário e pode também ser aplicado em caso de multipropriedade edilícia, total ou parcial, não traz uma única menção à forma de divisão do pagamento do IPTU incidente sobre o imóvel predial, caso esse seja urbano. Na verdade, a lei só trata da obrigação tributária em análise uma única vez, quando determina, no artigo 1.358-T e seu parágrafo único, que o multiproprietário só pode renunciar ao seu direito de propriedade em favor do condomínio edilício e desde que esteja em dia com suas obrigações, inclusive com o pagamento dos tributos imobiliários.

Parte do texto do artigo 1.358-J foi objeto de veto presidencial, a exemplo do parágrafo quarto, que afastava a solidariedade entre os multiproprietários. Mesmo com esse veto presidencial, os civilistas Carlos Eduardo Elias de Oliveira (2018) e Gustavo Tepedino (2019), em artigos publicados em sítios eletrônicos, defendem a tese de que não há solidariedade entre os proprietários da mesma unidade, em face da autonomia das matrículas determinadas pelo artigo $2^{\circ}$ da nova lei, que alterou o artigo 176 da Lei $n^{\circ}$ 6.015/73. O primeiro doutrinador citado neste parágrafo inclusive sustenta que a cobrança do IPTU de forma solidária seria inviável, em razão da regra do artigo 110 do $\mathrm{CTN}$, que veda à lei tributária modificar o alcance, a definição e o conteúdo de institutos, conceitos e formas de Direito Privado.

\footnotetext{
7 A solidariedade além de ser um tópico do Direito Civil é também um fato ético, sendo necessário um aprofundamento sobre a questão (MASSINI-CORREAS, 2020).
} 


\section{OS ARTIGOS 109 E 110 DO CÓDIGO TRIBUTÁRIO}

Logo, a problemática lançada deveria ser analisada também tendo como fundamento os limites conceituais impostos pelo Direito Privado. Referida lógica pressupõe, em primeiro lugar, que há um arquétipo de tributação, delimitado por normas gerais de Direito Tributário com origem na Constituição Federal e no CTN -, que é impositivo à lei tributária que cria o imposto.

Isso implica dizer que a Constituição, ao definir a competência tributária, inicia a delimitação dos possíveis fatos geradores e das respectivas obrigações tributárias: o arquétipo da tributação. Deve-se extrair do modelo constitucional as possibilidades semânticas da norma impositiva de tributo, destinadas a necessariamente informar os legisladores no exercício da competência tributária. Ao se criar o imposto, deve-se reproduzir o que conceitualmente já fora definido pela Constituição Federal, seja referente aos elementos da hipótese (aspecto pessoal, material, espacial, territorial), seja relativo aos elementos da obrigação (sujeito ativo e passivo, base de cálculo e alíquota).

Não obstante, em raras situações, os critérios adotados pela Constituição mostram-se suficientes à definição de um arquétipo a ser igualmente seguido pelas ordens jurídicas parciais. Por conseguinte, atribui-se competência à lei complementar nacional para a resolução do conflito de competência e para a edição de norma geral sobre os fatos geradores, as bases de cálculo e os contribuintes dos impostos enumerados constitucionalmente. Com isso, vai-se fechando o arquétipo da norma impositiva tributária, a ser observado pelos legisladores no momento da criação do tributo.

Dessa sistemática, ressai o debate acerca da impositividade do Direito Privado ao Direito Tributário. Isso, porque a realidade tributada, não raro, é oriunda originariamente do Direito Privado (negócios jurídicos nominados e inominados). Pode-se afirmar que o Direito Tributário é um direito de sobreposição, que incide sobre realidades que se constituem sob a égide de outros ramos jurídicos. A questão se torna tanto e mais polêmica em virtude de a Constituição, ao delimitar a competência e, consequentemente, ao iniciar a modulação do arquétipo tributário, não raro se utilizar de institutos do Direito Privado. Olhos postos nessa situação, e na busca de previamente solucionar a disputa pelo método hermenêutico a ser 
utilizado na interpretação do Direito Tributário, o Código Tributário Nacional traz em seu bojo os artigos $109^{8}$ e $110^{9}$.

Sobre o assunto, Luís Eduardo Schoueri (2014, p. 773) pondera que na "análise dos conteúdos tanto do artigo 109 como do 110 do Código Tributário Nacional, vê-se o problema comum: cabe ao intérprete/aplicador determinar, à luz do contexto, se está diante de um instituto de Direito Privado". A consideração aos institutos do Direito Privado, ainda ressalta Sacha Calmon Navarro Coêlho (2006, p.), é inderrogável ao intérprete do Direito nos casos em que seus institutos são utilizados na tipificação legal da hipótese:

[d]iante desses dispositivos, parece inegável que o legislador brasileiro teve como pressuposto, em sua formulação, duas considerações fundamentais: (a) a lei tributária visa, precipuamente, ao conteúdo ou efeitos econômicos do fato tributável, e não à sua exteriorização formal; e (b) sendo autônomo, o direito tributário pode, em princípio, alterar as categorias de direito privado, de que se serve, para atuação mais eficaz de suas normas. Vale dizer, o legislador brasileiro aceitou as premissas da teoria da prevalência econômica consagrada no Código Alemão (cuja exatidão, aliás, não se pode realmente negar), mas opôs sérias restrições à admissibilidade de todas as consequências dela extraídas. Especialmente opôs a reserva de que a assemelhação das situações econômicas idênticas para fins de tributação idêntica deve partir sempre do legislador, ao expressamente desprezar a diversidade de formas jurídicas sob que se apresentam, e nunca do aplicador da lei. É como dissemos, o Direito Tributário admite a atribuição de efeitos fiscais aos institutos de Direito Privado, porém por lei, nunca por interpretação livre da Administração. [...]

Sob essa vertente, defendeu-se a interpretação literal no Direito Tributário a afastar a interpretação econômica ou a teoria do abuso de direito e do propósito negocial. Como consequência, deferiu-se menor liberdade ao intérprete e ao legislador na delimitação da norma impositiva tributária: caso o instituto do Direito Privado fosse utilizado na definição da competência ou na criação legal do tributo, ele seria impositivo ao Direito Tributário. Ademais, em referidas situações, ter-se-ia que adotar uma perspectiva rigorosamente sistêmica, na qual se teria de extrair do instituto do Direito Privado todas as consequências conceituais aos vários elementos da norma impositiva de tributo. Não obstante, o Supremo Tribunal Federal (STF) tem relativizado o rigor ao sistema, do que são exemplo as

\footnotetext{
8 "Art. 109. Os princípios gerais de direito privado utilizam-se para pesquisa da definição, do conteúdo e do alcance de seus institutos, conceitos e formas, mas não para definição dos respectivos efeitos tributários." (BRASIL, 1966)

9 "Art. 110. A lei tributária não pode alterar a definição, o conteúdo e o alcance de institutos, conceitos e formas de direito privado, utilizados, expressa ou implicitamente, pela Constituição Federal, pelas Constituições dos Estados, ou pelas Leis Orgânicas do Distrito Federal ou dos Municípios, para definir ou limitar competências tributárias." (BRASIL, 1966)
} 
considerações do Relator no RE $n^{\circ}$ 651.703/PR, no qual se discutia a qualificação dos planos de saúde como serviços:

[o] Tribunal asseverou, ainda, que a chamada "Constituição Tributária" deve ser interpretada de acordo com o pluralismo metodológico, abrindo-se para a interpretação segundo variados métodos, desde o literal até o sistemático e teleológico. Por isso, os conceitos constitucionais tributários não são fechados e unívocos, devendo-se recorrer também aos aportes de ciências afins para a sua exegese, como a Ciência das Finanças, a Economia e a Contabilidade. Dessa sorte, embora os conceitos de Direito Civil exerçam papel importante na interpretação dos conceitos constitucionais tributários, eles não exaurem a atividade interpretativa, conforme assentado no julgamento do precedente acima referido.

Não obstante a flexibilização do rigor sistêmico entre Direito Civil e Direito Tributário, ele não foi afastado, mas apenas matizado pelo método teleológico, econômico e finalístico. O que, inclusive, guarda consonância com o próprio Direito Privado, cujos institutos são, na sua grande maioria, tipos abertos, aos quais o próprio Direito Privado tem atribuído uma vontade objetiva que informa, para além da vontade imediata e explicitada pelas partes, a definição tipológica do negócio jurídico. Ou seja, também no Direito Privado a linguagem conceitual silogística mostra-se insuficiente à qualificação jurídica das suas realidades. O econômico passa a ter relevância.

O fato é que ainda que matizados por elementos econômicos, os institutos do Direito Privado são elementos delimitadores (ou, conforme sustenta Schoueri, o contexto), que exercem importante função de sistematicidade e segurança jurídica no Direito. Está-se a dizer que o instituto do Direito Privado é um elemento a necessariamente se levar em consideração, na determinação não apenas do aspecto material da hipótese de incidência como dos seus outros aspectos (pessoal, territorial, espacial) e dos elementos da obrigação tributária, sempre que possível. Como exemplo, volta-se ao caso que se enfrenta no presente artigo: ao se arguir que o conceito civil de multipropriedade é o contexto fático/jurídico no qual se realiza a tributação, em razão de que o instituto propriedade é expressamente utilizado pelo constituinte e pelo CTN na delimitação da competência tributária dos municípios, ter-se-ia de verificar se dele é possível extrair quem seria a pessoa com ligação direta e pessoal com o fato gerador (art. 1.021, I/CTN): em outros termos, quem é o titular da riqueza tributada, o contribuinte.

Em matéria do IPTU, o CTN, ao verificar que o direito de propriedade, conforme o regulado no Direito Civil, possibilita o exercício de diversas faculdades que apresentam grandeza econômica própria, fragmentou o fato gerador da regra matriz em cada uma delas, 
individualmente considerada, atribuindo a cada titular específico das diferentes faculdades a natureza de contribuinte (o que foi compreendido como constitucional pelo STF, ao ressaltar que é possível excluir da imunidade recíproca o imóvel de propriedade de pessoa jurídica de Direito Público, quando a sua posse, por particular, se der no interesse privado deste ou/e na exploração de atividade econômica - informativo 861/STF). Dessa feita, independentemente de a multipropriedade ser Direito Real ou Obrigacional, em se caracterizando a propriedade ou a mera posse tem-se por existente o fato gerador, delimitado em seus aspectos pessoal e material.

Isso implica dizer que tanto a propriedade como a posse são fatos geradores do tributo, de maneira que tanto o proprietário como o possuidor a qualquer título (que são os seus titulares) podem ser o contribuinte. Com isso, supera-se, conforme o antecipadamente concluído, a questão da relevância da natureza jurídica da multipropriedade (de Direito Real ou Pessoal). Mas a questão referente à solidariedade permanece, assim como a pertinência da ressalva de que nela não há situações de fato ou jurídicas concomitantes, mas que se sucedem, tanto que possuem matrículas distintas.

O exposto no parágrafo anterior denota uma dificuldade prática, já que a existência de várias matrículas para o mesmo bem, regulado no artigo $2^{\circ}$ da Lei 13.777/2018, que alterou o Código Civil e Lei dos Registros Públicos, não afasta a unidade do bem em multipropriedade, que será regulado em convenção própria. Essa questão será desenvolvida no tópico 06.

\section{DIREITOS QUE SE SUCEDEM}

Se a riqueza e o respectivo direito da qual se reveste são sucessivos, questiona-se acerca de qual a propriedade ou a posse se caracteriza como fato gerador do IPTU. Referida questão revela-se importante, prima facie, em razão do aspecto temporal do fato gerador do IPTU:

[o] dilema parece exigir que se enxergue, na antecipação ora retratada, a figura de ficção jurídica: o legislador considera o factum ocorrido em $1^{\circ}$ de janeiro. Ou, o que dá no mesmo: o legislador empresta a um factum que surge a partir de uma série de circunstâncias que se dão durante o ano, o regime jurídico dos fatos que ocorrem em $1^{\circ}$ de janeiro. Há, nas ficções, mera remissão normativa, de modo a conectar a uma hipótese legal a sanção que é consequência de outra norma. O legislador, no caso, dá a um fato jurídico tributário cujos elementos se espalham ao longo do ano 
calendário, o consequente normativo daqueles que se dão no dia $1^{\circ}$ de janeiro. (SCHOUERI, 2014, p. 522-523).

Essa é uma forma de se ver a questão. Outra, é aquela que sai da ficção e que se apega à natureza econômica e jurídica da propriedade e da posse: eles são situação de fato e de direito permanente, ou seja, que se protela no tempo ${ }^{10}$. O cerne da questão, considerando o fato gerador do IPTU, é o ano calendário, sendo a posse ou domínio de pessoas diferente relevante para legitimidade da cobrança em conjunto ou não naquele período.

Efetivamente, torna-se necessário recorrer a uma ficção legal para se definir o momento em que se encerra, anualmente, o fato gerador, para fins de incidência tributária, mas tal não altera a realidade jurídica e econômica da propriedade - a de que não se realiza instantaneamente, num átimo de tempo: a situação é continuada e permanente.

Referida ressalva é importante para se definir a sujeição passiva em matéria de multipropriedade, conforme se passa a explanar.

\section{SUJEITO PASSIVO DO IPTU E MULTIPROPRIEDADE}

Ao se iniciar este tópico, ressalta-se que a sujeição passiva é diversa do aspecto pessoal da hipótese de incidência, o que tem causado muita confusão, não obstante o CTN tenha delimitado em seu artigo 121 que a pessoa obrigada legalmente ao pagamento do tributo pode ser o contribuinte ou o responsável. Já no seu artigo 128, o diploma dispõe que um terceiro que tenha algum vínculo com o fato gerador (salvo o pessoal e direto, que qualificaria o contribuinte) pode ser chamado por lei para realizar o pagamento da obrigação tributária principal de pagar tributo.

Não obstante distintos, eles estão em íntima conexão. Isso, porque a obrigação tributária tem por causa jurídica um evento pessoal, cujas consequências também devem ser pessoais. Melhor explicando: existem duas razões jurídicas aptas à coação pelo tributo, a riqueza e a remuneração. Nos tributos de fato gerador não vinculado, o dever fundamental de pagar o tributo surge em razão da riqueza, ou seja, porque se é titular de uma riqueza apta ao custeio dos gastos gerais do Estado. Já em um tributo de fato gerador vinculado, o pagamento

\footnotetext{
${ }^{10}$ Ainda quanto ao elemento temporal do fato gerador do IPTU, José Jayme de Macêdo Oliveira (2011, p. 339) arremata: "A primeira observação é no sentido de que o fato gerador do IPTU é periódico, continuado, o que significa que sua materialização se dá tão só diante do estado de fato "ser proprietário de imóvel urbano", para tanto desimportando atos ou fatos verificados em certo período. Releva apenas que alguém detém o domínio daquele bem, e nada mais".
} 
é feito porque se deve retribuir ao Estado a despesa que ele teve ao atuar ou criar benefício específico para determinada pessoa. Aqui, a razão tributária é de troca e remuneratória. Não por menos, Sacha Calmon Navarro Coêlho (2000, p. 585) fala que a obrigação tributária é do tipo pessoal. Ou seja, como a razão de tributar se explica numa causa atribuída personalissimamente ao contribuinte (riqueza e retribuição), cabe a ele sofrer o impacto econômico da tributação.

Para melhor se aclarar, imagine-se que não se revestiria de qualquer lógica tributária a atribuição do pagamento do imposto de renda de uma pessoa adulta e capaz ao seu pai. Afinal, uma pessoa sofre a incidência do imposto de renda porque possui riqueza; por sua causa, é chamada a contribuir com os gastos gerais do Estado. Essa é uma obrigação personalíssima, que também se dá no IPTU: aquele que é o contribuinte - o titular da riqueza apta a sofrer a tributação - deve arcar com o respectivo ônus econômico. Isso não significa, entretanto, que por razões de praticidade um terceiro não possa ser chamado; mas, se assim for, deve sê-lo em condições especiais.

Ou seja, um terceiro só deve ser chamado para a sujeição passiva se dispuser de mecanismos de ressarcir-se, econômica e previamente, junto ao contribuinte, do ônus do tributo. É o que ocorre em relação à fonte, no IR: embora o titular da riqueza seja quem está a receber os rendimentos, quem paga o tributo possui meios de ressarcir-se, econômica e previamente, junto ao contribuinte, do respectivo ônus, ao descontar o equivalente ao imposto da quantia que está a pagar ao contribuinte.

Dessa forma, um terceiro pode ser chamado a realizar o pagamento do tributo, desde que disponha do instrumental adequado para repassar o respectivo ônus econômico ao contribuinte, antes do pagamento do tributo. Isso é o que significa ter relação com o fato gerador. Existe, contudo, uma outra circunstância em que um terceiro pode ser chamado: quando, mediante o descumprimento de uma obrigação acessória, prejudica a atividade de aplicação e cobrança do tributo. Assim foi como, em julgado do STF (RE no 599.628/DF, informativo 607), caracterizou-se a sujeição passiva e se a distinguiu do contribuinte.

Ou seja, o sujeito passivo pode ser o contribuinte, sempre, ou um terceiro, neste último caso desde que se observando as situações no parágrafo anterior tratadas. Eis a relevância de se definir o contribuinte: a) ele sempre pode ser sujeito passivo (é desejável, inclusive, que o seja, pelo parâmetro da justiça tributária); b) na definição do terceiro como sujeito passivo, deve-se delimitar o contribuinte para estruturar-se o(s) mecanismo(s) do ressarcimento econômico junto a si do responsável, caso a sujeição passiva não surja em 
razão de ilícito. Dessa forma, a delimitação da sujeição passiva não decorre da identificação do contribuinte, como se se tratasse de uma mesma realidade, o que é tão comum de ocorrer no IPTU. E para afastar-se qualquer confusão nesse sentido, a Súmula n 399 do Superior Tribunal de Justiça (STJ) aduz que "cabe à legislação municipal estabelecer o sujeito passivo do IPTU.".

Ademais, as pessoas que estiverem implicadas em uma mesma situação fática e jurídica que caracterize o fato gerador do tributo e da responsabilidade, são chamadas a pagar em conjunto a obrigação tributária principal, independentemente de específica previsão legal (art. 124/CTN).

Sistematizando-se os conceitos apresentados no propósito de se responder ao problema que ora se enfrenta, pode-se assim expô-lo: o sujeito passivo pode ser o contribuinte (proprietário ou possuidor); o sujeito passivo pode ser um terceiro, desde que possa ressarcirse do ônus econômico junto ao contribuinte ou que tenha praticado um ilícito com prejuízo da fiscalização e arrecadação tributária; c) aqueles que estejam implicados na titularidade da riqueza ou na prática do ilícito são chamados ao pagamento do tributo.

Quanto à caracterização do contribuinte, já se explicitou que pode ser o proprietário ou o possuidor. Não obstante, o problema verifica-se na característica da multipropriedade, por ser temporal, e na delimitação de um dia específico para a incidência do IPTU $\left(1^{\circ}\right.$ ou 31 de janeiro de cada ano, na maioria das legislações municipais). Nesse caso, apenas quem esteja no gozo da propriedade ou da posse da fração que corresponda ao período de incidência seria considerado o contribuinte? Em sendo assim, não se poderia estender a sujeição passiva aos demais proprietários e possuidores que o irão suceder e que o antecederam?

Há um primeiro momento, conforme se antecipou, em que se propõe tratar o IPTU não como um fato gerador instantâneo que se limite à data que o legislador municipal estipule para a ocorrência do fato gerador, mas como um fato gerador continuado, antecipado ficticiamente para uma data no início do exercício, o que implicaria que várias das frações, englobadas no período de um ano, estariam susceptíveis a sofrer incidência do IPTU, pois a realidade econômica e jurídica é permanente.

Vai-se, contudo, além, para considerar que no caso todas as frações estão implicadas na configuração do fato gerador, de maneira a incidir o artigo 124 do CTN. O posicionamento inverso iria estar em desconformidade à natureza jurídica da multipropriedade, que foi regulada no Direito brasileiro como uma forma especial de condomínio edilício. $\mathrm{O}$ fato de a propriedade, naquele determinado lapso de tempo, estar individualizada não afasta o caráter 
indivisível da propriedade, nem o direito de cada multiproprietário de responder solidariamente sobre o todo, caso em que a sub-rogação é utilizada para se reaver as quotas dos demais.

Ante tal contexto, a equiparação de tratamento de multiproprietário ao condômino, determinada pela Lei $n^{\circ}$ 13.777/2018 e já aceita no âmbito do Direito Civil, é estendida ao Direito Tributário, pois implica um conjunto de pessoas que tenham interesse comum na situação que constitua o fato gerador da obrigação principal: o direito de propriedade e o eventual direito de posse se dirigem a um mesmo bem específico, cuja propriedade e o exercício de suas faculdades encontram por limite, é exemplo, a função social, da qual uma manifestação das mais relevantes consubstancia-se no dever fundamental de pagar imposto.

A solidariedade constitui um instituto do Direito Civil, inscrito no Livro I - Do Direito das Obrigações, de suma importância para outras áreas do Direito, sendo certo que não se presume - ou vem expressamente determinada no negócio jurídico ou determinada em lei. Institui um benefício ao credor que se vê legitimado a cobrar de qualquer dos devedores a dívida de forma total ou parcial, conforme previsão no artigo 275 do Código Civil, tornando o exercício do seu direito de melhor execução, já que possui pluralidade de patrimônios para satisfazer seu crédito.

No Direito Tributário, que nada mais é que o conjunto de regras para regular as obrigações de natureza tributária, o instituto da solidariedade está presente em inúmeros dispositivos, entre eles o já mencionado artigo 124, que possibilita a cobrança do tributo de forma solidária, deixando claro, segundo Machado (2014, p. 150), que a solidariedade tributária não comporta benefício de ordem e que o pagamento efetuado por um dos contribuintes aproveita aos demais (p. 151).

No caso dos multiproprietários, em sendo incontroverso que a nova legislação estabeleceu um liame entre eles, passando a considerá-los condôminos, é possível à Fazenda Pública municipal que regula a cobrança do Imposto sobre a Propriedade Predial e Territorial Urbana (IPTU) estabelecer procedimentos de cobrança solidária desses, em conformidade com a regra geral do artigo 124 do $\mathrm{CTN}$, em sendo o contribuinte, nos termos do artigo 34 do CTN, o sujeito passivo (o que, de regra, ocorre).

Tal procedimento de cobrança solidária é importante, sendo impensável a cobrança fracionada pelos municípios de cada multiproprietário em conformidade com sua fração ou período do tempo que pode exercer de forma plena sua propriedade na unidade imobiliária em questão. Todos têm o interesse comum na coisa, na sua conservação, no seu bom uso, na sua 
adequação às regras jurídicas que regulamentam a propriedade, dentre as quais se destaca uma vez mais o cumprimento da sua função social, seja urbanística, rural e social, esta última a revelar-se no dever fundamental de pagar imposto. O interesse é comum e não se pode, por formalismos e ficções temporais, sobrecarregar apenas um seu interessado, sob pena, e isso para se restringir apenas ao Direito Tributário, de se instituir tratamento diferenciado para quem se encontra em igual situação (art. 150, II/CF), com prejuízo específico à capacidade contributiva (art. 145, § 1\% CF).

Até porque, em Direito Tributário, o IPTU e os tributos que incidem sobre o imóvel adquirem status de ônus real, e isso, justamente pelas regras que regulamentam a responsabilidade por sucessão (art. 30/CTN). Ou seja, aqueles que vão sucedendo temporalmente na titularidade, passam a ser responsáveis pelo pagamento: o IPTU agrega-se como ônus real ao imóvel, e ainda que não se estivesse a tratar de condomínio que implica os condôminos no mesmo fato gerador, ter-se-ia a responsabilidade por sucessão apta a ser antecipada em razão da possibilidade de se cobrar o tributo antes da ocorrência do fato gerador (art. 150, $\S 7 \% \mathrm{CF}$ ): no caso, fato gerador da responsabilidade.

O fato da existência de matrícula individualizada para cada fração de tempo não destrói os argumentos defendidos neste artigo, pois essas matrículas sempre estarão vinculadas ao registro da unidade autônoma, sendo que aquela apenas estabelece a fração de tempo e permite a aquisição da propriedade desta fração. O que se defende neste ponto é que a matrícula individualizada está atrelada há um registro da unidade como um todo, devendo existir uma convenção de multipropriedade que faça a divisão do uso no tempo. Logo, defende-se que há um bem, cuja incidência do IPTU deverá ocorrer, sendo as matrículas por fração de tempo, após a divisão, reguladoras do condomínio em multipropriedade.

Ressai evidente, portanto, a presença do interesse comum entre os multiproprietários na propriedade sobre a unidade autônoma e na obrigação do pagamento solidário do Imposto sobre a Propriedade Predial e Territorial Urbana (IPTU) incidente sobre o imóvel, conforme enuncia Schoueri (2014, p. 553):

[i]nteresse comum só têm as pessoas que estão no mesmo polo na situação que constitui o fato jurídico tributário. Assim, por exemplo, os condôminos têm “interesse comum" na propriedade; se esta dá azo ao surgimento da obrigação de recolher o IPTU, são solidariamente responsáveis pelo pagamento do imposto todos os condôminos. Note-se que o débito é um só, mas todos os condôminos se revestem da condição de sujeitos passivos solidários. 
Em síntese, tendo por base que o último artigo citado trata especificamente do IPTU, o município de Fortaleza já efetua cobrança em nome de apenas um dos proprietários que conste do cadastro, sendo viável a cobrança de todos os proprietários pelo mesmo imposto territorial de forma solidária. Essa regra também consta do Código Tributário do Município de Curitiba, especificamente em seu artigo $34^{11}$. O fato da citada legislação ser anterior a Lei 13.777/2018, seu texto pode ser aplicado há casos de condomínios especiais, como o instituído na referida lei.

Ressalta-se também que a argumentação para a cobrança solidária dos multiproprietários é válida tanto em caso de multipropriedade (time-sharing) em uma única unidade habitacional ou não residencial ou em caso de multipropriedade em edifício, isto é, quando todo o edifício possui suas unidades autônomas afetadas com o regime do timesharing, ainda que a Lei $\mathrm{n}^{\mathrm{o}} 13.777 / 2018$ faça distinção entre multipropriedade e multipropriedade em condomínio edilício.

Não resta dúvida de que essa questão é nova e continua gerando intensos debates, sendo interessante ressaltar que em pesquisa jurisprudencial realizada em 08/2019 nos sítios do Superior Tribunal de Justiça (STJ) e do Tribunal de Justiça de São Paulo (TJSP) utilizando-se os filtros multipropriedade e solidariedade e IPTU, não foi encontrado qualquer registro de julgado.

A questão do dia primeiro de janeiro é apenas um termo, já que o fato gerador é a propriedade ou posse predial em determinado exercício. O que relevante, no caso de multipropriedade, repete-se, é que o bem pertence aos multiproprietários, pouco importando a fração ideal de cada ou o tempo de uso destinado, sendo certo que a cobrança pode ser realizada de forma solidária, caso haja previsão legal, não perdendo de vista que o bem imóvel em multipropriedade é uma, existindo espécie de condomínio sobre a unidade, com as características próprias tratadas no Código Civil após 2018.

A condição de o fato gerador ser periódico não desvirtua a conclusão apresentada de que em face da natureza jurídica atribuída pela nova legislação (13.777/2018) o multiproprietário $^{12}$ é um condômino, sendo plenamente possível os Municípios cobrarem o

\footnotetext{
11 “Art. 34. O contribuinte do imposto é o proprietário, o titular do domínio útil ou o possuidor do imóvel. Parágrafo Único. Quando um imóvel possuir mais de um proprietário, titular do domínio útil ou possuidor, o imposto será lançado, à critério da Administração, em nome de um destes, o qual assumirá a qualidade de responsável solidário tributário." (CURITIBA, 2001)

${ }^{12}$ Sobre a equidade, teoria da aplicação direta ou indireta das normas de direito fundamental e a importância da reforma legislativa para a construção de um regramento que traga segurança jurídica, considerando a constitucionalização por irradiação, vide Rodrigues Júnior (2019, p. 220)
} 
IPTU de forma solidária desses. Tal conclusão não ocorrerá em caso de multipropriedade atípica (multipropriedade pessoal ou acionária) - dada a possibilidade de o proprietário da unidade imobiliária tributada ser apenas uma pessoa jurídica -, cujos estatutos permitem a concessão da posse a cada um dos detentores de direitos obrigacionais. Em síntese, não há que se falar em solidariedade, já que não há pluralidade de proprietários.

\section{CONCLUSÃO}

A multipropriedade imobiliária, a partir da Lei $\mathrm{n}^{\circ}$ 13.777/2018, possui natureza real, tendo, antes disso, a jurisprudência do STJ acatado esse entendimento, equiparando esse instituto ao do condomínio.

Essa forma de organização da propriedade vem se revelando um instrumento apto a incrementar o mercado imobiliário nacional, funcionando como elemento propulsor da atividade turística, bem como propiciando a aquisição de imóveis de veraneio por um custo mais baixo mediante o exercício do direito dominical pelos multiproprietários individuados em frações de tempo.

Na multipropriedade típica, regulada pela Lei $\mathrm{n}^{\circ} 13.777 / 2018$, o empreendimento ou unidade pertence a todos os multiproprietários, a quem caberia uma fração ideal, constituindo uma espécie de condomínio ou condomínio edilício, regulado pelo Código Civil de 2002, a depender de sua instituição, sendo, portanto, Direito Real.

$\mathrm{O}$ tratamento que vem sendo emprestado à multipropriedade imobiliária no âmbito do Direito Civil é o do regime de condomínio horizontal, o que permite ao Direito Tributário considerar a relação de solidariedade entre os multiproprietários quanto ao fato gerador do Imposto sobre a Propriedade Predial e Territorial Urbana (IPTU), porquanto embora haja temporalidade no exercício do direito dominical, afigura-se a perpetuidade na titularidade do direito à propriedade e o domínio comum sobre o mesmo bem.

A nova legislação, estudada neste artigo, estabeleceu um elo entre os multiproprietários, passando a considerá-los condôminos, o que os implica no interesse comum sobre a coisa, na sua conservação, no cumprimento da sua função social, que tem como uma de suas manifestações o dever fundamental de pagar imposto. Em suma, todos são responsáveis pelo bom uso da coisa em conformidade com o regime jurídico. A ser de forma diversa se teria o que se considera em ambiente restrito do Direito Tributário prejuízo à isonomia, nos termos do artigo 150, inciso II, da Constituição Federal, e da capacidade 
contributiva, conforme regulamentada no artigo 145, parágrafo primeiro, da mesma Carta, uma vez que pessoas com a mesma riqueza (igualmente proprietárias ou possuidoras de um bem) seriam tratadas de forma tributariamente diversa, por arbitrariedade na fixação do aspecto temporal da hipótese. A situação, é esta a conclusão, enquadra-se no artigo 124 do CTN: todos os diversos multiproprietários e possuidores são contribuintes pois implicados no fato gerador do tributo e podem (devem) ser chamados à cobrança solidariamente, em sendo o contribuinte o sujeito passivo.

De outra sorte, ainda que a propriedade não fosse fato gerador continuado e que a multipropriedade não implicasse condomínio ou a situação descrita no artigo 124 do CTN, poder-se-ia arguir o caráter de ônus real do IPTU que circula entre os titulares sucessores do imóvel, nos termos do artigo 130 do CTN.

Em síntese, afasta-se a ideia de fracionamento do IPTU na multipropriedade para, por meio de ficção jurídica, considerar-se realizado o seu fato gerador conforme a data instituída em lei municipal para sua ocorrência, já que o fato jurídico se perfectibiliza por meio de uma sucessão de eventos ao longo de determinado período eleito pelo legislador como suficiente para gerar a obrigação tributária principal.

\section{REFERÊNCIAS}

BRASIL. Lei $n^{o}$ 5.172, de 25 de outubro de 1966. Dispõe sobre o Sistema Tributário Nacional e institui normas gerais de direito tributário aplicáveis à União, Estados e Municípios. Disponível em: http://www.planalto.gov.br/ccivil_03/leis/15172.htm. Acesso em: 30 jul. 2019.

BRASIL. Lei $n^{\circ}$ 13.777, de 20 de dezembro de 2018. Altera as Leis ${ }^{\circ}{ }^{\circ} 10.406$, de 10 de janeiro de 2002 (Código Civil), e 6.015, de 31 de dezembro de 1973 (Lei dos Registros Públicos), para dispor sobre o regime jurídico da multipropriedade e seu registro. Brasília: Presidência da República, 2018. Disponível em: http://www.planalto.gov.br/ccivil_03/_ato2015-2018/2018/Lei/L13777.htm. Acesso em: 30 jul. 2019.

BRASIL. Superior Tribunal de Justiça (3. Turma). Recurso Especial 1.546.165/SP. Relator: Min. Ricardo Villas Bôas Cueva. Rel. Min. João Otávio de Noronha, 26 abr. 2016. Disponível em: https://scon.stj.jus.br/SCON. Acesso em: 30 jul. 2019.

CAMARGO, Juliana Werneck de. O IPTU como instrumento de atuação urbanística. Belo Horizonte: Fórum, 2008.

COÊLHO, Sacha Calmon Navarro. Curso de direito tributário brasileiro. 9. ed. Rio de Janeiro: Forense, 2006. 
CONSELHO DA JUSTIÇA FEDERAL. Enunciados Aprovados na $1^{\text {a }}$ Jornada de Direito Civil: Enunciado 89: "O disposto nos arts. 1.331 a 1.358 do novo Código Civil aplica-se, no que couber, aos condomínios assemelhados, tais como loteamentos fechados, multipropriedade imobiliária e clubes de campo." Brasília, DF: Centro de Estudos Judiciários do Conselho da Justiça Federal, 2002.

CURITIBA. Lei complementar $n^{\circ} 40$, de 18 de dezembro de 2001. Dispõe sobre os tributos municipais e dá outras providências. Revogando as Leis $\mathrm{n}^{\circ}$ 6.202/1980, 6.457/1983, 6.619/1985, 7.291/1988, 7.832/1991, 7.905/1992, 7.983/1992, Lei Complementar nº 17/1997 e Lei Complementar no 28/1999. Curitiba: Prefeitura Municipal, 2001. Disponível em: https://www.curitiba.pr.gov.br/conteudo/legislacao-tributaria/104. Acesso em: 30 jul. 2019.

FERNANDES, Cintia Estefania. O Imposto Predial e Territorial Urbano sob a égide da progressividade constitucional aplicada. São Paulo: Quartier Latin, 2011.

MACHADO, Hugo de Brito. Curso de Direito tributário. 35. ed. São Paulo: Malheiros, 2014.

MASSINI-CORREAS, Carlos I. Existem direitos de solidariedade? A tradição clássica e as propostas liberais. Revista da Faculdade de Direito da UFRGS, Porto Alegre, n. 42, p. 45-62, abr. 2020. DOI: https://doi.org/10.22456/0104-6594.102156.

MELO, Marcelo Augusto Santana de. Multipropriedade imobiliária. Revista de Direito Imobiliário, v. 70, ano 34, p. 19-80, jan./jun. 2011.

OLIVEIRA, Carlos Eduardo Elias de. Considerações sobre a recente Lei da Multipropriedade ou da Time Sharing (Lei no 13.777/2018): principais aspectos de Direito Civil, de Processo Civil e de Registros Públicos. In: TARTUCE, Flávio. Considerações sobre a recente Lei da Multipropriedade: Artigo de Carlos Eduardo Elias de Oliveira. Jusbrasil, São Paulo, Artigos, 26 dez. 2018. Disponível em: https://flaviotartuce.jusbrasil.com.br/artigos/661740743/consideracoes-sobre-a-recente-lei-damultipropriedade. Acesso em: 30 jul. 2019.

OLIVEIRA, José Jayme de Macêdo. Impostos Municipais. 2. ed. São Paulo: Saraiva, 2011.

RODRIGUES JUNIOR, Otávio Luiz. Direito civil contemporâneo. Estatuto epistemológico, Constituição e direitos fundamentais. São Paulo:Forense, 2019.

SANTOS, Juliana Cavalcante dos. A função social da propriedade urbana sob o ponto de vista do Estatuto da Cidade. São Paulo: Editora Revista dos Tribunais, 2014.

SCHOUERI, Luís Eduardo. Direito Tributário. 4. ed. São Paulo: Saraiva, 2014.

SIQUEIRA, Marcelo Sampaio. Direito de Construir. 2. ed. Curitiba: Juruá, 2018.

SIQUEIRA, Marcelo Sampaio; SIQUEIRA, Natercia Sampaio. A perda da multipropriedade imobiliária por usucapião. Revista Jurídica Da UNI7, v. 14, n. 2, p. 65-80, 2017. DOI: https://doi.org/10.24067/rju7,14.2:481. 
TEPEDINO, Gustavo. Multipropriedade imobiliária. São Paulo: Saraiva, 1993.

TEPEDINO, Gustavo. A multipropriedade e a retomada do mercado imobiliário. Revista Consultor Jurídico, 30 de janeiro de 2019. Disponível em: https://www.conjur.com.br/2019jan-30/tepedino-multipropriedade-retomada-mercado-imobiliario. Acesso em: 30 jul. 2019.

VENOSA, Sílvio de Salvo. Lei do inquilinato comentada. Doutrina e prática. $15^{\circ}$ ed., São Paulo: Atlas, 2019.

\section{DADOS DA PUBLICAÇÃO}

Categoria: artigo submetido ao double-blind review.

Recebido em: 20/09/2020.

Aceito em: 12/07/2021. 